\title{
"This Job is a Solid Killer": Oliver Harrington's Jive Gray and the African American Adventure Strip
}

\section{Edward Brunner}

By the time of World War II, the adventure strip that Milton Caniff had been developing since 1934 in Terry and the Pirates - a more or less sophisticated tale, oriented to adult interests - had established a set of narrative conventions that were sufficient enough to permit others to work variations upon them. Central to these conventions was a commitment to "realistic" art based on a style used by magazine illustrators rather than cartoon sketches. Sometimes in collaboration with Noel Sickles (at the time producing Scorchy Smith), Caniff pushed the representational realism of magazines further by drawing on techniques borrowed from motion pictures to lend an aura of animation to his panels. As Jennifer Hayward points out in her detailed examination of the strip, these included "narratively significant landscapes, increased use of shadow and texture, [and] experimentation with camera angles to reinforce narrative signals" (108). The Caniffean adventure strip was more than just sophisticated drawing, however. As Hayward notes, in Caniff, romance is inseparable from adventure. Terry and the Pirates unfolded in a fantasy version of the far east, an orient remote enough from civilization to evoke "frontier" standards of justice in which the integrity and ingenuity of individuals were tested. Under such conditions, the relations between men and women were under pressure, open to modification, adjusted according to circumstances. Those who were weak, those who might have been victims under more usual circumstances, had the opportunity to rise to the occasion and reveal their strength as events tested their mettle. But Caniff added one other ingredient to this refurbished formula for melodramatic adventure tales. A master of carefully-constructed dialogue, Caniff endowed his characters - even minor ones - with remarkable verbal skills. His char-

Edward Brunner, a Professor of English at Southern Illinois University, Carbondale, has written Cold War Poetry: The Social Text in the Fifties Poem (Illinois, 2001). He is completing an extended study of "adventure" strips in American newspapers between 1930 and 1960. 
acters never simply spoke: they engaged in a witty repartee. As his feature evolved, his characters also matured and became even more dazzlingly clever. Figures in the strip were often based upon actual persons who made brief cameo appearances as themselves or who served as models for ongoing characters.

The "Caniff-Sickles tradition" as comics historian Ron Goulart calls it (143-158) had become a significant presence on the funny pages by the late 1930s and in comic books of the early 1940s, from the Charlie Chan who appeared in newspaper strips drawn by Alfred Andrioli (who had been an assistant for Caniff) and such once-popular features such as The Adventures of Patsy drawn by Charles Raab (another Caniff assistant) to the early versions of The Sandman in Adventure Comics in 1940 drawn by Allen B. (Bert) Christman. No variant, however, so radically realigned important aspects of that tradition as Oliver Wendell Harrington's Jive Gray, an adventure strip designed for readers of African American newspapers that appeared in the weekly Pittsburgh Courier from 1943 to 1951. Like Caniff's strip, Jive Gray presented itself as entertainment: a fast-moving adventure tale that unfolded in a serial narrative among the other comic strips on the page reserved for such things. Thomas M. Inge was first to set forward the links between Caniff's "Terry Lee" and Harrington's "Jive Gray": both were young fliers in the armed forces, with Gray a "Tuskegee Airman," one of the select group of African Americans trained to fly fighter aircraft. Inge compared panels from Caniff in 1942 and Harrington in 1943 to reveal Harrington's mastery of what he called "Caniff's penchant for authentic backgrounds, authoritative detail, and realistic rendition" (xxx). But if Jive Gray began in homage to Caniff, it quickly became a series that worked out plot twists, character developments, and most important of all, sharply-delineated but subtly encoded vignettes that were particularly relevant to a black audience. Politically engaged, subtly confrontational, darkly acerbic, it was in fact a decisive intervention in the tradition of male-oriented adventure strips, and especially in its postwar reincarnation, it revised as much as it borrowed from the Caniffean formula. Indeed, Jive Gray was less a variation on Terry and the Pirates than an extension of the assumptions of the adventure strip itself. Harrington's strip deployed the formula of the mass culture adventure strip to address the political circumstances that surrounded African American culture in the 1940s, sometimes simply remarking upon them, sometimes directly addressing them, sometimes confronting them with an approach that verged on the radical.

\section{I}

Oliver Wendell Harrington (who sometimes signed his strips "Ol' Harrington") was an African American born in 1912 who grew up in the South Bronx, a child of a racially mixed marriage. He began contributing cartoons to black newspapers in 1933 while studying at the National Academy of Design and later, while working toward a B.F.A. at Yale, from where he graduated in 1939. Before and after Jive Gray, Harrington also produced for newspapers a long-running one-panel gag feature, Dark Laughter, that sketched the misadventures of Bootsie - a black man with few resources, trying to make his way in an urban setting that reflected all too harshly the lack of opportunity for him and for many others like him (Harrington 

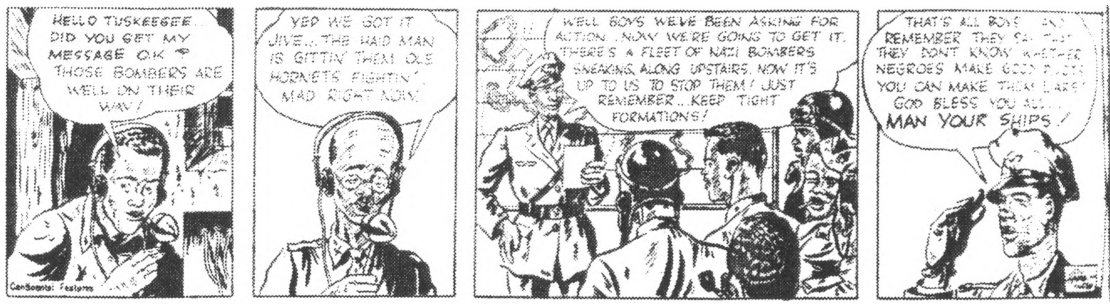

Figure 1. In his inaugural episode, Harrington includes a guest appearance by the Tuskegee Airmen's Commanding Officer, Colonel Benjamin O. Davis, Jr.

always showed others speaking, never Bootsie). In 1948, while furnishing new adventures for Jive Gray as well as continuing Dark Laughter, Harrington accepted the job of Director of Public Relations for the NAACP, a position in which, in Lucy Caswell's words, he "worked diligently in the south long before sit-ins publicized the need for justice for minorities there" (Caswell 68). Under pressure from groups investigating leftist dissidents, he left the country in 1951, and in Paris, was welcomed by a community of expatriate black artists that included Richard Wright and Chester Himes. In 1961, in Germany, he remained behind on the eastern side when the Berlin Wall was installed, and from then on he contributed primarily to European newspapers until his death (Caswell 67-70, Mazyck 30-42).

Given this background, the fact that Harrington's Jive Gray had a strong undercurrent of the political is not surprising. But then no comic strip - and certainly no adventure strip that tilted toward an adult readership - was expected to stray too far from the political agenda supported by their syndicates and the newspaper chains that operated them. The directions taken in Jive Gary are best understood in light of the politics of the Pittsburgh Courier which was, in the early 1940s, on the way toward overtaking the Chicago Defender as the black weekly with the largest circulation, a feat it would attain when its circulation reached 270,000 at the very point when Harrington's strip was regularly appearing. Although the Pittsburgh Courier included among its contributors such strong conservative voices as George Schuyler, it was also one of the black weeklies always ready to lean conspicuously leftward - like Adam Clayton Powell's Harlem-based weekly, The People's Choice (for which Harrington served for a time as Art Director and where an earlier version of Jive Gray, in which Gray is an investigative reporter, appeared for only three weeks in 1942). Early in 1942, the newspaper embraced a program known as "DoubleV" which soon spread to other black papers. "The first V for victory over our enemies from without, the second V for victory over our enemies within," wrote James G. Thompson (a 26-year old cafeteria worker in a Cessna manufacturing plant in Wichita, Kansas) in a letter to the Courier that proposed the concept. "For surely those who perpetuate these ugly prejudices here are seeking to destroy our democratic form of government just as surely as the Axis forces" (Washburn 55).

Throughout the war, the Courier was quick to remind its readers that many of the freedoms fought for in the war still remained essentially unavailable to most African Americans (Scott and Womack 166-167, Washburn 100). When the American War Department began, in 1940, to plan for the likelihood of military action, it was Robert Vann, publisher of the Courier, who insisted that the government 
recognize African Americans as a group to be trained as fighter pilots in the upcoming war. The newspaper had been an early supporter of black aviators, running feature stories on figures such as John Robinson, a pilot who engaged in air combat with Italian planes while delivering medicine to civilians and soldiers, and James Peck, a pilot who had served the Loyalists in the Spanish Civil War (Scott and Womack 52, 64 65). One sure sign of the Courier's willingness to pursue unpopular proposals was the extent to which it was singled out by J. Edgar Hoover for prosecution during the war for its "Double V" campaign and other matters. Again and again, Hoover pressed charges against the Courier (and other black newspapers), arguing that their demands for equality were seditious insofar as such critique aided the enemy. Only the unswerving resistance of Francis Biddle, the U. S. Attorney General, kept these charges from going forward (see Shaw 48-127, Washburn.)

The Courier's editorial positions were on display in the opening episodes of Jive Gray. Indeed, the strip's debut on May 8, 1943, may have been inspired by the arrival in April 1943 of the first group to graduate from the Tuskegee program, the $99^{\text {th }}$ Pursuit Squadron in North Africa. Their transfer had been preceded by a lengthy discussion among military and government bureaucrats as to whether they would enter combat or - like another group of pilots controversially trained during the war, the WASPS (women's air force auxiliary) - be limited to ferrying supplies and equipment. The first episode of Jive Gray dramatically confronts this controversy by offering a scenario that imagines the air space around America suddenly penetrated by enemy bombers (figure 1). Nice questions about whom should fight who, when, and under what conditions are set aside as the Tuskegee Airmen, geographically closest to the advancing enemy aircraft, take to their planes and, though newly-fledged as fighter pilots, dispose of the bombers in a matter of ten or twelve panels in three or four weekly episodes. To an audience trained in the nuances of aerial warfare - in 1943, not a small number - it would be clear that the enemy would have dared to dispatch bombers, notoriously slow-moving planes, only because the enemy had presumed no fighter pilots would be on hand to guard the bomber's presumed targets.

The first weekly episodes of Jive Gray confine themselves to a story-line that focuses on accurately-drawn aircraft engaged in aerial combat. Once the Tuskegee Airmen have successfully destroyed enemy bombers, however, Harrington turns toward issues of political importance to Courier readers. Gray, who has returned to the States, notices one of his companions has parachuted from a disabled plane, and lands his fighter and sets out to find his fellow airman. Both he and the injured pilot are taken captive by a white man with a rifle who treats the fallen flyer as if he were a criminal whose punishment will be along traditional southern lines. "A'right ... You boys put yo hands up high ... an' keep 'em up, y'all," the white man says, continuing to speak in the next panel: "Now you boys start to walkin' an' no funny stuff or I'll po' some good lead inta ya!" To which Gray replies: "But this man's been shot ... he can't raise his hands." The white man (in the last panel): "Guess he's been shot, huh? Well, he's the black ape we're lookin' fouh. There's gon' be a good ole lynchin"" (24 July 1943). This reaction in which a white man assumes an injured black man must be the criminal who should be the object of vigilante action 
registers the outright hostility with which the Tuskegee Airmen were greeted by locals. Harrington also invites us to observe that it is a white southerner who speaks in the dialect of the uneducated while the northern black man has a perfect command of English. Even at this early stage, Jive Gray proposes not only to indicate the incidents in a black history that might otherwise go unrecorded but also to challenge and even reverse stereotypical assumptions of superiority.

Although this four-panel episode, printed in the week of July 24, 1943, leaves us at a point of maximum suspense, the next episode would not appear until September 4,1943 . Over the six-week interim - a period, incidentally, in which the race riot in Detroit that had broken out in June was under intense discussion by all media - the single white man has multiplied into a mob ("my boys back hyer is just itchin' to fill yo' black hide with some lead birdseed") and in a later sequence, they are marching to "some secret lair" (18 September 1943). Clearly the direction of the strip underwent significant change during this crucial period. Information about a "secret lair" associates the mob with the launching site of the bombers. And when another Tuskegee Airman appears in the skies to rescue Gray and the downed flier, the mob produces a military-style machine gun that they plan to fire against the new airplane. This is a particularly audacious moment of reversal: an ineffectual attempt by a lynch mob to shoot down an Army Air Force fighter. It also provides a lesson in the superior firepower that is now in the hands of the Tuskegee Airmen. Indeed, when Harrington shows the exchange of gunfire between the mob and the fighter plane, he quickly conveys just how unequal these opponents are. We are left with the distinct impression that the mob has been eliminated by the military airship, which would have been equipped with multiple machine guns and a cannon: they were not merely routed but actually executed. This action appears in an episode comprised of only two panels, in which the second panel shows clearly and dramatically the agony inflicted upon lynch mob members who writhe in pain. Although the lives of enemy soldiers could always be purchased cheaply in the panels of comic strips once the war was underway, these who were challenging Gray and his friends were not enemy soldiers but American citizens. But from the perspective of the Courier's "Double V" campaign there would be no significant difference between those who practice racism at home and those who promulgate fascism abroad. In later episodes, southern whites will regularly reveal themselves as traitors who have aligned themselves with axis powers.

This first set of episodes, produced from May through December 1943, end triumphantly. Gray and his fellow-airmen have been rescued from the southern mob that has been radically "dispersed," and they land at their home field under the concerned eyes of a tall, thin Army Air Corps Colonel, while an Army nurse at the rank of a sergeant speaks over a microphone to direct an ambulance toward the landing planes. In what might have been the final panel if this had been a one-timeonly sequence, Harrington closes with a visual homage to the group of female African American nurses (and clerks and mechanics) who were a vital part of the Tuskegee base, as well as a sketch of Benjamin O. Davis, Jr., the first African American in the twentieth century to graduate from West Point and the commanding officer of the $99^{\text {th }}$ Pursuit Squadron (Homan and Reilly, 58, 94-95, 97). Since a 
Davis-like figure had also appeared in the first episode, where the fliers were being addressed by one described as the head man, the depiction of Davis in the final panel of this episode could have brought an appropriate sense of closure to the eight-month long sequence.

If Harrington had created this sequence alone, his achievement would have been noteworthy. As a feature that portrayed young black males engaged in a historic mission, such a project decisively challenged the iconographic tradition of mainstream newspapers that crudely stereotyped African Americans and that represented them as incompetent brutes, more physical than intellectual. Robin Mazyck observes, in her pioneering analysis of Harrington's wartime strips, that his achievement in these opening sequences is to undermine "the legitimacy of Jim Crowism" and to demonstrate that African Americans perform successfully under pressure and when given major responsibilities (81). Harrington's drawing also brandished that sense of responsibility. His highly accurate visual reconstructions, depicting P-39 and P-40 fighters downing German bombers, was more than an echo of the documentary-like drawing style that Caniff had mastered. In this context, Harrington's ability to compete with Caniff was a further confirmation that black men were equal to anyone in their ability to achieve mastery of their art - as the Tuskegee Airmen were also demonstrating in their own way. In addition, Harrington aligned the Jim Crow policies of the south with the ideologies of fascist regimes abroad. The lynch-mob mentality that Harrington sketched in his episodes was less a fantasy and more an allegory of actual race relations for the Airmen who had volunteered to fight for their country. After all, the Airmen's base in Alabama had been designated as "All-Negro" by the military and it included its own theaters, mess halls, PX and officers' clubs. But outside the base, conflicts arose once blacks - especially those from the north - encountered the segregations of Tuskegee, where in fact most of the white officers lived (Scott and Womack 161). Finally, Harrington also advanced a visual convention for the representation of dark skin that acknowledged its color altered under various circumstances. The same character could appear to have a skin that was darkly shaded at times but virtually unshaded at other times. At once skin color is reduced in importance without being denied or dismissed. It is a matter of the way light falls, contingent upon the particular occasion, never an unchanging hue.

\section{II}

Jive Gray resumed, without fanfare, in February 1945. In the fourteen months since the strip had ended, Harrington had served a stint as a war correspondent for the Courier, and the return of Jive Gray coincided, in the one-panel gags of Dark Laughter, with Bootsie joining the infantry as a foot soldier. As Harrington was sketching the misadventures of Bootsie, he was also unfolding new adventures for Jive Gray. While the two features were superficially opposites - Bootsie in the army was just as inept as Bootsie in Harlem, while Jive Gray was unflappably urbane, remarkably gracious and always enterprising - in one respect they were similar: in both, Harrington was increasingly willing to bring racism to the forefront of his material. His panels, moreover, offered a sharp counterweight to the view of the 
DARK LAUGHTER . . . . By OL' HARRINGTON

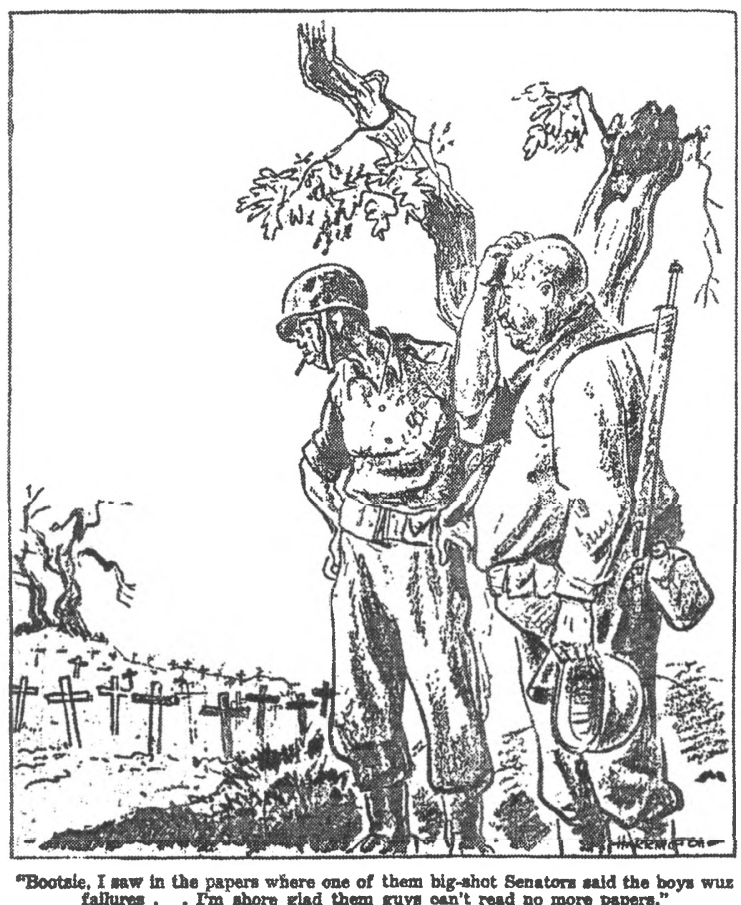

Figure 2. What Bill Mauldin couldn't draw: black combat veterans mourning "boys" who died to bring freedom to others far from American shores. military on display in the immensely-popular "Willie and Joe" works by Bill Mauldin, whose collection of panels with commentary was published in 1944 as Up Front. Even though Mauldin reported on events in southern Europe, including the Italian front where African American squadrons were stationed, he regularly portrayed a war fought entirely by whites. By contrast, Harrington revealed not only the presence of an African American military but one which blacks ands whites brushed up against one another, often awkwardly. More specifically, in Dark Laughter Harrington recorded his first indications that the end of the war would not produce a new harmony between whites and blacks.

Although a number of the one-panel gags in Dark Laughter were designed just to elicit a laugh, there were others that spoke directly to the problems of racism. For example, Bootsie and a black friend are seated in an old-fashioned open-air horsedrawn carriage, and their driver is an obviously European figure in a large moustache. The caption reads: "This shore ain't Mississippi, is it Bootsie?" (16 June 1945). Some Dark Laughter panels merged recent news stories with the viewpoint of the front-line soldier. Bootsie and a black friend look over an area that is filled with the crude crosses of a makeshift graveyard. Gnarled trees, unnaturally broken, are in the foreground and background (figure 2). The caption reads: "Bootsie, I saw in the papers where one of them big-shot Senators said the boys wuz failures ... I'm shore glad them guys can't read no more papers" (14 July 1945). But Harrington reserved his sharpest critique for panels that addressed male-female relations. Bootsie is seated at an outdoor café with an attractive young woman who seems comfortable in the Italian surroundings. Another couple, neither of whom is black, are seated in the background. A waiter hovers attentively near that other couple, but three MPs stand just behind Bootsie and his companion, glowering fiercely, 
while a fourth MP begins to make his way over. The woman is speaking: "Whenever I go out with brown Americanos there are so many meelitary poleece. Thee sees a great complimento the brown Americanos, yes?" (19 May 1945).

Like these sharp commentaries in Dark Laughter, the Jive Gray strips that Harrington produced between 1945 and 1951 frequently presented direct references to current political situations, including the relations between men and woman across racial lines, the lack of employment for black pilots at civilian airlines, the rampant poverty that marked the urban ghetto, unjust treatment by the police, and numerous examples that revealed how profoundly segregation had become institutionalized. But while Harrington remained sharply conscious of such issues, he never centered his strip on any one of them directly. Rather than pursuing an openly-leftist narrative that directly confronted examples of racial injustice, he opted instead to produce an adventure strip with heroic black Americans as its main characters, but which also happened to be set in a realistic social environment, one that conveyed the feel of the postwar world as it appeared to African-Americans, where examples of injustice were so indelibly a part of daily life that anyone who belonged to a minority culture would naturally allude to them. Such a careful balancing act would have had numerous antecedents in the African American community of the 1940s which had grievances to air and triumphs to post and urgently sought venues for such activity. Jubilee, the World War II radio show produced by the Armed Forces Radio Service, was ostensibly a variety show that simply highlighted the talents of black entertainers, but through its choice of musical selections, its comedy routines, and its use of visiting guest stars, it became "a potent space for artistic freedom," as described by Lauren Rebecca Sklaroff, with performances that "both subtly and directly critiqued discrimination, gender roles, and white expectations of black performance" (969).

When Harrington revived his strip, one of the most striking changes he introduced was not visual but verbal, and it addressed the title character's name. In this respect, too, Jive Gray starkly diverged from Dark Laughter. The convention in the one-panel gag was that Bootsie never spoke, he was always spoken to. His silence was not just a mark of a general silencing, in which speech from blacks was less than welcome (though it surely conveyed that overtone), but more often a silence that invited readers to join Bootsie in contemplating the ironies and the contradictions that Harrington was setting forward. By contrast, Jive Gray was thoroughly articulate, for the most part speaking in phrases that were grammatically proper, pointedly avoiding even a hint of that dialect that whites had imposed on blacks by way of the minstrel tradition. (Characters in the strip who do speak in a lumbering dialect are, like the leader of the lynch mob in the opening episode, likely to be white southerners.) There are only a few moments when Gray lapses from what might be called American Standard English, but they are significant. "This job is a solid killer!" he enthused when given a demonstration ride in a new jet, but he almost immediately apologized, realizing his companion (a female Russian colonel) might not comprehend. More often others, especially young black men, spoke in this new discourse, in a mix of slang, colorful metaphor, and highly-compressed (almost codified) allusion that were a form of "jive talk." When Gray was address- 
ing a sidekick and needed to insist on a point, he dropped into exactly that kind of speech, a gesture that signaled both urgency and comradeship. Trying to warn his friend Waterloo against the advances of a femme fatale whose nickname was "the Jaguar," Gray spoke: "Relax and let this soak in. That smooth gazelle is a finger! We've got to play heads up ball from here on in or they're going to put us down and down means six feet of it!" (8 May 1948).

Of course emphasis on virtuoso slang was, in newspaper strips, a matter of long tradition. Defining slang as "a vocabulary regarded as below standard and that threatened proper, genteel ways," Irving Lewis Allen credited "the newspapers' syndicated comic strips early in this century" as a "powerful force for spreading slang" which he characterized as the "street speech of the period" that "expressed the troublesome spirit of the social underside of the industrial city: unconventional, experimental without license, insubordinate, scornful of - or merely careless of authority" $(18,23)$. In the majority of those early newspaper strips at least one significant character, and often several, spoke a vivid demotic English. The slogans that R. F. Outcault pasted on the convenient space of the Yellow Kid's shift in the days before word balloons had become fully conventional were always vernacular wisecracks. Even when comic strips lost much of their rowdiness in the decades following their origin, as they began in the 1920s to center on the domestic suburban family rather than urban gangs of kids, that raucous element remained as a trace in the perennial interest in the vernacular as spoken by secondary characters. Caniff's Terry and the Pirates, always sensitive to particularities of language, continued to develop characters that openly devastated standard English. In 1945, he introduced Charles C. Charles ("Hotshot Charlie") from Boston who spoke a linguistic slumgullion that was an uncategorizable mix of slang, revamped cliché, rhyme, and obscurely compressed phrasings. Responding to Terry Lee's concern that young April Kane might be planning to marry him even though he hadn't proposed to her, Hotshot Charlie replies (in the last words of the four-panel daily of 12 October 1945): “Oh, get him, Gertie! He's so old-fashioned he thinks a dollie actually waits around for the bended knee business once she's made up their minds!" (1992 n.pag.). This was a kind of talk that was supposed to be distinctively "American," and in a Sunday sequence in Terry and the Pirates from February 23, 1941, Burma - the "entertainer" with a shady past - secretly communicates to an imprisoned Terry Lee by speaking a patois of Pig Latin, tabloid history, and swing music references that she delivers to the bafflement of Terry's jailers: "Ixnay, Podnuh! High pockets with the solo cheater probably has a party line on this clambake! The big ick is a dillinger - but he can't collar the jive!" (1989 n.pag.) Here "jive" is nominalized as a code language in which only the young can communicate, which is distinctive to street-wise Americans, and which is marked by verbal adroitness and elaborate metaphor.

For Harrington, however, such talk was not figured as "American" but as the special lingo of a postwar generation. The term "jive," slang dictionaries report, is derived from Wolof words "jev" and "jew" that meant "gossip, false talk, con game." With its first registered appearance in Louis Armstrong's 1928 recording "Don't Jive Me," jive talk began as deliberately misleading, deceptive nonsense 
("Jive" in Major 259, in Cassidy 143-144). But by the postwar years, "jive" had merged with the chatter of bebop scat-singing to become a rapid-fire scattershot phrasing that was rhythmically inventive, verbally excessive, but also complexly fashioned to conduct conversations that outsiders simply could not hear. A sequence from the rare Hollywood film with an all-black cast, Stormy Weather (1943), staged a moment in the evolution of this term: when young and ultra-hip band leader Cab Calloway sees that his elder, the one-time vaudeville dancer Bill ("Bojangles") Robinson, is baffled by the stream of inventive phrases pouring from a young friend's mouth, Calloway explains to his friend that Robinson "don't understand that jive." Though Robinson and Calloway share a musical heritage as inventive black performers, a generation gap opens between even them (Buhle and Wagner 189-191). When considering such talk as it passed among musicians, Eric Lott could describe it as one might characterize bebop jazz - as a "closed hermeneutic" designed to have the "undeniable effect of alienating the riff-raff and expressing a sense of felt isolation, all the while affirming a collective purpose" (460). In Harrington, however, such talk is presented in a less elitist manner, as the vivid speech of a wartime generation that clearly demonstrates a kind of linguistic mastery that in no way resembles the inept and shuffling dialect that an earlier generation was presumed to use.

Not all of the examples of vivid speech in Jive Gray clearly belong to blacks. When a military plane is disabled by an invisible ray (wielded by ex-fascists who are determined to rule the world), its apparently non-black pilot greets disaster with ironic wit: "order the crew to step out on some clouds pronto all four motors are out! I'll park her right up here and walk home ..." (24 January 1948). Indeed, G I. Jive was the name of a popular Armed Forces Radio Service daily show that featured jazz and swing played by white and black performers. For many white Americans, "Jive" was simply shorthand for fast-paced swing songs played by the big bands that dominated popular music in the 1940s. And when Bing Crosby filled the role of drop-in guest for a segment of Jubilee he read from a script that demonstrated that this was the way one musician might communicate with another. Asked by African American host Ernie Whitman "On what fleecy cloud did you float in?" Crosby amicably replied: "Well, Ernie, I happen to pass your solid door every week, and I've been knocked out" (Sklaroff 967). (It is notable that when Crosby uses such language, he is not speaking down to an inferior but adjusting himself to the terms of another culture.) Harrington, however, understood there was a virtuoso jive talk that existed beyond the kind of modish phrasing that Crosby employed, and he reserves the most startling elocutions, the most extreme examples of jive talk, for young black characters who are utterly articulate in a new language that telegraphs its meanings cryptically.

Two of the acquaintances that Gray makes in his adventures speak a jive-bop slang so fluently that it serves as their only means of discourse. In an episode from 1948-1949, when Gray learns that the fascists in a Latin American country are assembling their armies for some future campaign, he himself is deep in enemy-held territory. When he radios for help from the loyalists who had employed him as a pilot, the only help that arrives is the figure of a jive-talking pilot from Philadelphia 
who has parachuted out of an airplane wearing a wide-brim fedora that was obviously designed to accessorize a zoot suit and who is initially called "Jiver Rowe" but who inexplicably becomes, in the next week's adventures, "Doc Bogart." His opening speech is just outrageous enough so that he is at first dismissed by Gray as a ridiculous, even a comic figure. 'Greetin's daddy ... I'm the reenfo'cements they promised. Jiver Rowe is the label, right out'a Philly ... Heard you cats needed some flash in your war so I hopped a dee-cee four and joined up with you hosses ... Nothin' cookin' in Philly nohow ..." (1 January 1949; ellipses in the original). But Gray soon realizes how completely he has underestimated him once he begins to train the local natives to be disciplined fighters. With this character, Harrington suggests that American slang in the form of jive represents a potent lingua franca that usefully identifies the most sagacious and innovative members of a young generation. Harrington underscores this in a speech he gives to Gray: "Back in the states he'd be called a Zoot-suiter with every cop on the block savin' him up for a slow Monday ... Give him somethin' to believe in an' treat him like a man an' he's pure poison to the opposition!"' (19 February 1949; ellipses in original).

Jive Gray's first name, then, is not designed simply to be a claim on his blackness, though it surely is that, but also a sign of his modernity, a link with a new youth culture that moves swiftly and unhesitatingly into the future. And if such speech unites individuals, it does so by permitting them to deliver messages that the dominant culture may not want to hear, and it thus stands as a sign of their shared alienation. Though jive talk may offer itself as a rare opportunity for crosscultural sharing, a place in which young whites and young blacks find themselves temporarily able to exist on a level ground, this element is rarely on display in Harrington's strip. Earlier in this same episode, Gray had met another pilot, "Loco Crow," a Native American who spoke an equally fluent jive. When Gray's sidekick asks Loco Crow why he wears his hair in a long braid, adding: "You don't have to jive these folks down here. This is "cross the border," Crow answers in a way that implies his name is an ironic variant on Jim Crow: "that old crow named James only flies as far as the border up in the old country, but doc, I got used to wearin' this jive. It was good to me in Alabama so I'm gonna be good to it here!" (12 June 1948).

The solidarity invoked here between different ethnic groups - the racial lines during the war dividing "white" from "colored" would have also snared native Americans - parallels the extent to which, in Jive Gray, it is whites who are in the background, and whenever they do appear, they are either monsters or fools, either bestially violent Nazis or semi-idiotic southern racists. For Harrington, after 1945 the war against fascism continues because African Americans are still second-class citizens, still likely targets for genocidal "solutions." To the rest of the world, the war has ended decisively, but as historian Roger Daniels reminds us, for African Americans in the postwar years the world perhaps looked even changed for the worse: "Not only had little real progress been made, but the war years at home had witnessed a number of race riots, most seriously in New York City, Detroit and Los Angeles" (165-166). Indeed, a postwar heritage in which the fighting seems never to have ended was predicted early in the strip. When Gray forces down a B-29 in Air Corps markings that has been firing upon him, the white man who emerges from the 
plane confronts him: "You negroes are trying to run America, but the Nazis haven't lost yet. An' we have powerful friends in America!" (8 September 1945). According to nationalist leaders in a Latin American country who employ Gray to ferry supplies to partisans, there are many "ex Nazi officers" who remain "not conveenced that their new order is really fineeshed" (3 April 1948).

News that such fascist groups still exist does not get disseminated because the media is corrupt and prejudiced. When a wire service reporter with a conspicuous southern accent learns that Gray's airplane is missing, he envisions a headline story with a specific slant: " 'Only Cullud Air-line Pilot Crashes, All Passengers Lost!' Brother, that's juicy, man!" (“I ain't tellin' you not to write your story like you just said," Gray's sidekick says menacingly as he collars this journalist, but "if you do, you'd better put some pepper and salt on your typewriter! It'll taste better ... do you dig?") (September 18, 1948; ellipses in original). Sometimes this racial conflict can be handled with finesse or at least treated deftly. "We ought to be back in the states in about five hours," Gray says, as he and Waterloo fly out of the Caribbean at the end of one adventure, to which his sidekick replies, in the punch line of the last panel: "Let's not hit the coast any further south than New Jersey" (9 November 1946). At other times, racial conflict is cast in terms that allow only for sharp divisions, as in the exchange between officers in the South African military who are pursuing African rebels. "I say commander, the blacks seem to have bolted," says one as their convoy passes an abandoned diamond mine. "Never saw a black who'd stand up to a white man old boy!" replies the other (8 July 1950). (Of course the army led by these two will be attacked by the rebels when they least suspect it.) The single exception to this negative portrayal is the ship captain who, in a 1949 sequence, had resisted an order to dispose of Gray on the high seas. After the ship is unexpectedly sunk, and Gray and the captain are thrown together on a life raft, Gray nurses the captain back to health.

\section{III}

If this demonization of whites in Jive Gray appears to be excessive, it may nevertheless be an accurate register of the everyday reality experienced by African Americans and that black newspapers often recorded. And of course it scarcely compares with the manner in which African Americans had been demeaned, since the earliest days of the newspaper strip, in brutal caricatures. In the words of historian Bruce Lenthall, whose overview of pre-war newspaper comic strips is detailed and persuasive, blacks in those comic strips "appeared as less than human," looking "more like animals than people" (43). African American Novelist Charles Johnson reports Harrington as saying that white illustrators invariably drew Negroes as "a circle, black with two hotdogs in the middle for a mouth" (qtd. in Johnson 8). Crude caricature was hardly the case when Will Eisner drew the black sidekick "Ebony" in The Spirit, but Eisner's carefully-drawn figure reproduced in close detail a minstrelized image. What is especially dismaying about these caricatures is that they persist, as Ian Gordon has demonstrated in a study of a number of long-forgotten turn-of-the-century strips that employed African American characters (none of them drawn, however, by African Americans). During the 
very years when the continuing comic strip feature was acting as a crucial site for the normalization of ethnic types, from 1900 to 1920, no black cartoon character emerged who successfully enacted the transition out of ridiculous stereotype into beloved figure (Gordon 59-79). In these same decades, the Irish American evolved from abject caricature into recognizable human being in a course of thirty or so years. The Irish-American cop Milligan, in Chester Gould's Dick Tracy strips of the 1930s, is just one more policeman, drawn as a figure with standardized facial and physical features, with his Irishness only present in the trace that remains of his name (he speaks with not a hint of a brogue). By contrast, when "Memphis" Smith, an African American, joins the Dick Tracy strip as a brief continuing character in 1936, he appears exclusively as a comic figure, drawn as if he were in minstrel show make-up, with lips that are rubbery and that encircle his mouth, and he speaks with a heavy dialect. Tracy even addresses him, at least initially, in patronizing terms as "Big Boy" and "Snowball." Given the stylized iconography of Dick Tracy, in which the characters who were most visually grotesque were always the villains, "Memphis" Smith can never escape the onus of villainy (Gould 476, 477).

If the black figure was made to seem grotesque and unappealing in most newspaper strips, Harrington countered by using a realistic drawing style that avoided any semblance of the caricature and that depicts skin color through delicate shadings that allowed the darkness of skin to shift according to changing light sources. In conventional visual codes, "Race is what can be seen (and therefore named) in skin color, facial features, hair, etc.,"W. J. T. Mitchell reminds us. "Whiteness, by contrast, is invisible, unmarked; it has no racial identity, but is equated with a normative subjectivity and humanity from which "race' is a visible deviation" (162). Harrington confounds this expectation by refusing to have a single tone of color unchangingly representing the African American. A particularly elegant example of Harrington's ability to complicate and undermine a visual color line occurs in an episode published on June 10, 1950, and set, appropriately enough, in South Africa (figure 3). In earlier episodes, Gray has boldly kidnapped a physician and forced him to operate on Boola, a pilot who had been injured while flying supplies to a rebel army opposed to the regime in Pretoria that officialized the policy of apartheid in 1948. The fierce exchange that occurs in this episode between Candy Mason, Boola's close friend, and the physician who has reluctantly saved his life exposes the convictions on either side. But as Candy speaks back, she has the last word, and the effect is to plunge her adversary into silence and darkness, even as she
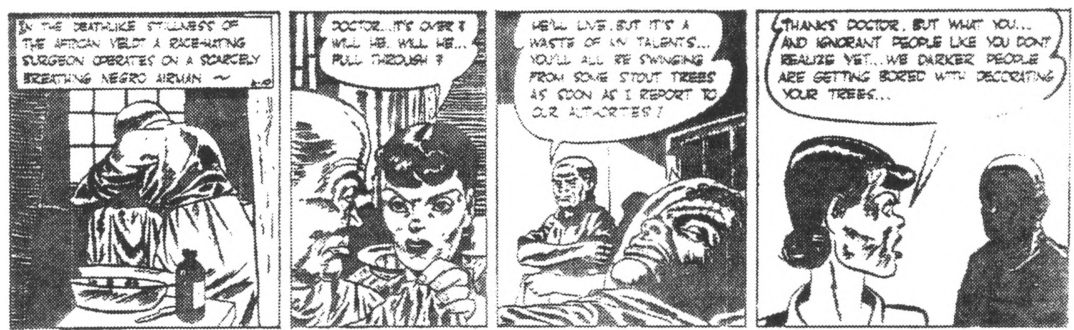

Figure 3. In an episode set in South Africa, a female pilot confronts a doctor who has saved a life only to look forward to his patient's death. 
embraces the description of "we darker people." The darkness that envelopes him in panel four is metaphorical, representing ignorance and the smugness of a ruling class that has access to the "authorities." Candy's impassioned rejoinder, no doubt exceptionally intense because the doctor's reference to lynching also evokes the racial history of America, deepens the hue of her face, precisely because it is flushed with anger. At the moment, she is a woman whose beauty is inseparable from her ability to speak back prophetically to a figure of authority. And if Boola, the patient who appears in panel three, now seems at rest, his face, so close to the foreground, looms over the physician. As the physician rolls down the sleeve of his shirt, he also appears to cradle himself as if he has been injured. It is the figure of authority, the doctor, who emerges as injured in the exchange. The one who had been injured, Boola the pilot, though prone and silent, seems to have his renewal assured. The alliance between Boola and Candy now seems powerful and beyond challenge.

Just as skin color is rendered complex through Harrington's visual representations, so is the issue of racial heritage and the taboo of crossing racial lines. His female characters especially emerge from a range of different ethnic backgrounds that Harrington signals less by any racially-inflected drawings than by verbal description. One of the earliest love interests in the strip is a Red Cross nurse who may be Eurasian (Pee Wee calls her a "sloe-eyed chick" - December 15, 1945) and when she boldly embraces and kisses Gray she calls him a "great big pretty hunk of P-51 chocolate fudge" (29 December 1945) - a compliment more fashionable than enduring, though absolutely the right thing to say at the time: the P-51 was the cutting-edge fighter plane that African American pilots mastered to great success in the last months of the war. Similarly, after Jive rescues Pee Wee from an adventure in a Caribbean island, the Princess of the islanders insists on returning home with them: "You didn't think I was going to let the yummiest men I've ever met get away, did you?" (23 November 1946). We know that the princess is the descendant of a lineage that includes Indian, slave and sailor, because Harrington has her described as such by smugglers admiring her looks. Jive himself marries a woman from Latin America whose name is Gina, though his continuing adventures take him some distance from her, even to Africa, where he impresses the strikingly-beautiful Queen Menalise. With such romances, Harrington sets forward instances that undermine "race" as a valid concept. And all such identities are signaled not by visual signs but verbal descriptions. It is Gina's name and her broken English that associates her with Latin America. What is also conspicuous about these many flirtations is that most happen outside the borders of the United States. Only in America, it seems, do questions of skin color absurdly divide adults from each other.

Grey's strong and glamorous women of color participate in what Joanne Meyerowitz has identified as a postwar strategy in African American magazines to "construct glamour and beauty as political issues in the fight against racism." Promoting the sex appeal of women of color was "a self-conscious defiance of racist white standards of beauty" (244). However, Harrington's women are not only youthful, physically attractive, and eager to engage in amours. Like Candy Mason, so quick to defend the injured Boola, they are also self-confident, independent, and authoritative. Indeed, the first time a woman makes an appearance in the strip, she 
is in the midst of a dangerous situation in which she is in total command. She introduces herself as Colonel Pushkin of the Soviet Army and, in the first plot-twist of the series after it resumes in 1945, she has been paired with Gray in a mission to recruit him to join an elite group, the World Security Police, as a pilot officer. Because the war ended just as this episode was getting under way, whatever Harrington had originally planned for Gray and Colonel Pushkin had to be quickly resolved, but even in a few weeks, Harrington was able to make a series of important points. Simply by placing a woman in charge of so significant an enterprise, Harrington was associating her with immense power. In addition, her project involved developing high-speed jet aircraft, a task that linked her directly with a technological future. And with the surname Pushkin, she was identified as a descendant of the great Russian poet who was also part African. When she and Gray share a test flight, Harrington most openly gestures toward a Russian-American bond that also signals the possibilities of positive relations between blacks and whites as well as between men and women. Harrington is also able to suggest that the Jim Crow laws that define some as second-class citizens have their counterpart in social attitudes that regard women as inferior to men. In the midst of all this symbolic activity, Harrington
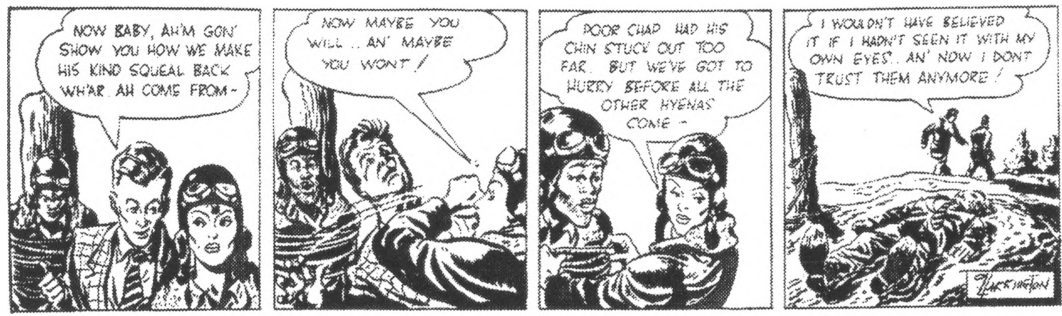

Figure 4. This southerner's plan to treat Jive Gray like an animal to be tortured is interrupted by Soviet Colonel Pushkin 's mean left fist.

also takes the opportunity to allude to the rockets that in fact harried the members of the African American 322nd Fighter Group in the waning months of the war.

Such a rocket, in another episode, shoots down the experimental jet that Gray and Pushkin are testing. (The sheer vulnerability of aircraft is never more on display than in Harrington's strip, where plot developments regularly hinge on the downing of a plane. Though the pilot in the plane is racially invisible, the sense of being targeted remains.) Captured, both Lieutenant Gray and Colonel Pushkin are interrogated not only by Nazis but by an American white male speaking in a southern accent and who lays claim to a stereotypical means of punishment - the whip (figure 4). But he has a fatal flaw which rests upon his ignorance of the new role that women have taken during wartime, an ignorance that parallels his inability to conceive African Americans in a new role. Assuming that she will be powerfully attracted to him, the Mississippian sets Pushkin aside, never thinking to bind her arms, and as soon as she has the chance, she drops him with her mean left fist. Failing to acknowledge the respect that women have earned at the end of the war, Harrington here conveys, may have dire effects. This informal "repeal" of unwritten laws governing the power relations between men and women also looks ahead to the ultimate demise of Jim Crowism. 
Harrington's strong women are always underestimated by racist villains. But even smart men, Harrington suggests, may fail to appreciate the autonomy that women should have won after their contribution to the war. In an episode from 1946, Red Cross volunteer nurse Lila Diller proposes to partner with Jive and Pee Wee in an air transport service that they plan as their new business. Sidekick Pee Wee complains that "she doesn't know a wing from a prop" in a set of panels in which they both happen to be admiring the flying stunts of a new fighter airplane above them, whose pilot, in panel four, is identified as - how can it be otherwise? Lila: "Hello, boys," she says, as she dismounts from the aircraft: "Just thought I'd go up to keep the old hand in. Borrowed this crate from the artillery boys" (12 January 1946). Harrington finds it important to stage encounters in which men find that they have vastly underestimated the power of women. When an airplane carrying relief supplies to African guerrillas is damaged in a fight with South African fighter-planes, it must be landed under emergency conditions that send it skidding across the airfield. When Gray and others rush to offer their aid, they extract a young woman from the plane then ask her who piloted it. It is Candy Mason, and she is the one who successfully landed the plane under emergency conditions. An issue in need of perennial discovery, it seems, is the ease with which the inferiority of another is assumed. In what would be the serial's final episode, even Gray momentarily errs. He is in Africa, and he expects that the beautiful Queen of a mythic African civilization will delegate a general to lead her army. Of course it is she who stands, on the next day, as the head of her troops. Even African Americans may have a lesson to learn about perception and prejudice.

In a series of episodes, Harrington develops this lesson, while also showing the power of language in shaping and reshaping attitudes. These episodes occur on a Caribbean island, in an incident in which Gray's sidekick Pee Wee also plays a central role, and they center on the glamorous woman who moves silently about and whom we know only as "Belle." She is addressed by Pee Wee as if she would barely be able to comprehend even the simple question he poses to her in basic English, but she answers in an elaborately modulated reply that indicates how much he has underestimated her intelligence. Several weekly episodes turn upon revelations that increasingly demonstrate first her competence, then her centrality, and finally her authority. It is she who rescues Pee Wee when he is attacked by a shark. Later, she directs a shadowy group of men in undercover operations. Ultimately, she is revealed as the queen of her tribe, a much-respected leader who has the trust of her people whom she directs in a revolt that breaks the hold of the smugglers.

When Pee Wee or Jive assume that natives either in the Caribbean or in Africa are just simple folk, they occupy a racialized point of view that is temporarily compatible with the readers of most of the other adventure strips in mainstream newspapers. One of many acolytes of Caniff was Frank Robbins, whose Johnny Hazard also followed the adventures of a pilot in wartime and after. In a sequence entitled "The Search for the Metal Lighter than Air," which ran from April 28, 1946, to September 29, 1946, and thus occurs almost simultaneously with the Pee Wee / Belle adventure, the dark-skinned natives that possess that lighter-than-air metal remain shadowy creature-like figures. Their dress helps show their alien quality: 

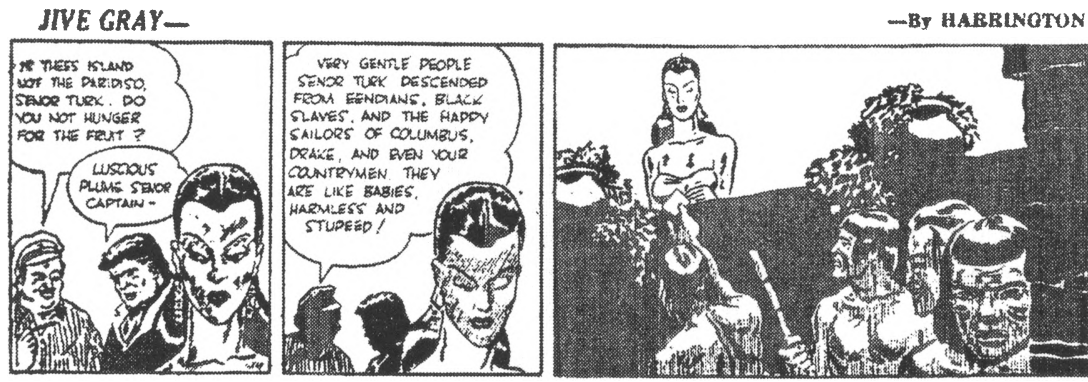

Figure 5. Harrington plays verbal flatulence against visual elegance in three nicelyplaced panels that end by bringing us to eye level with the natives.

they are covered in a loin cloth but wear peculiar pointed hats, as tall as their heads, that render them ominous - the hats are sharply pointed, like the swords they carry - as well as faintly absurd. Each man, though a dangerous warrior armed with a sword, also sports what looks like a brief skirt. Thus feminized, the figures are partly ridiculous, though threatening. However, the air of absurdity that surrounds them also suggests they can be tricked. When Brandy, Hazard's glamorous blonde companion, attempts to move among them in disguise, her helmet falls off, exposing her hair. But the natives then mistake her for Legon, a goddess, reinforcing what can only be called a hierarchy based on skin coloration (Robbins 1993 n.pag.). Harrington's sequences, by contrast, act as a corrective to such distant views of the "native" by dramatizing the extent to which even minorities who should know better have had their attitudes predetermined.

Harrington builds one of his weekly episodes around just such an underestimation (figure 5). With Belle's face in the foreground of an opening panel, we understand she is overhearing the speech of two of the men who have taken over the Caribbean island and in effect colonized the natives. After the conversation between smugglers reduces the island woman to luscious fruits of paradise, Harrington keeps us focused on Belle's face, which is now downcast as she hears the words of the captain, which seem to burden her (the two faces of the white men have now fallen into darkness): "Very gentle people, Senor Turk," the Captain is saying, "Descended from the Eendians, black slaves and the happy sailors of Columbus, Drake, and even your countrymen. They are like babies, harmless and stupeed!" (20 April 1946). But in the third panel, a group of muscular native males, hidden behind a wall marked with deceptively decorated pots, hand a note to Belle; the four are watchful, on guard, and may be armed (a stick is in the hands of one). Clearly, the third panel indicates that the natives are more organized than the others understand, that decorations which appear to be fanciful may in fact be effective material for covert operations, and there may be more to Belle than mere attractiveness (natives can read? And write?) People whom the Captain and Senor Turk are ready to dismiss as mere children or at best erotic plums to be devoured actually have a lineage that, as would be obvious to anyone who thought about it, must have depended on possessing strength and cleverness and survival skills. 


\section{IV}

If Jive Gray appears unduly episodic, even by the casual standards of the adventure strip, it should be noted that Harrington was laboring under the handicap of devising a feature that would be read in weekly intervals. While there were some adventure strips that appeared only on Sunday (Flash Gordon and Prince Valiant), such strips also enjoyed the enlarged space of the Sunday section in which to advance their stories. But once a week Harrington had available a space sufficient for only three, four or five sequential panels in which he had to allude to that which had previously happened, plus set in motion some event that would continue the story line, as well as make a particular point - a turn or a twist or a comment - that would be, in effect, the reader's reward for paying attention. Jive Gray at times suffered from this set of demands, and its inadequacies are especially evident when a series of texts that were designed to be read weekly texts are viewed in rapid sequence. Exposed, then, are the names of characters that mysteriously alter from one week to another: "Jiver Rowe" becomes "Doc Bogart"; the name of an African Queen is sometimes Menalise, sometimes Menalize; and "Lila Diller" - also spelled "Lilla Diller" - is used to refer to two different characters, a Red Cross nurse and a news reporter.

But Harrington's primary goal, it bears repeating, was to construct a framework that could display heroic black figures, notably but not exclusively young males, acting in a positive light, out of which they and other African Americans could speak authoritatively, with forcefulness. There are limits, of course, to conducting investigations of social problems within such a framework, especially when Harrington's extended narratives, the arc of which could easily take several months to complete, are primarily committed to revealing characters involved in heroic decisions in which they overcome adversity. Still, in several of the episodes that make up a weekly set of panels, Harrington is often quite interested in registering the social realities specific to life in a racist country. In a lengthy adventure that begins in 1947 and spills over into 1948, a white supremacist group has kidnapped a black scientist-professor and extracted from him, under torture, the secret for building an extraordinary invention, a cosmic ray that can disable airplane motors. Gray and his sidekick Waterloo and the professor's beautiful daughter (one of the two different characters who share the name Lilla/Lila Diller) uncover the group's lair in a remote mansion, where they battle the enemy and escape at the last moment, but without the professor. They speed to the police department to report these enemies and their mansion hideaway. Up to this point, the narrative has been more or less fantastic, involving secret inventions and kidnappings and last-minute escapes. Now it downshifts to a more practical reality (figure 6). When Gray is ushered into the chief's office, it is plain he isn't welcome, and when Gray reports the events, the chief expresses disbelief: "Am I supposed to believe this cock an' bull story?" (6 March 1948). Though we see policemen, in the final panel, piling into squad cars, what remains striking in this episode is the gulf that exists between white officials and black citizens, reminding us how much courage it requires for any black man to approach a white police officer. The skepticism expressed by these police, moreover, is likely to be remembered by readers of the next week's strip when it is revealed that all the white supremacists have somehow made a success- 

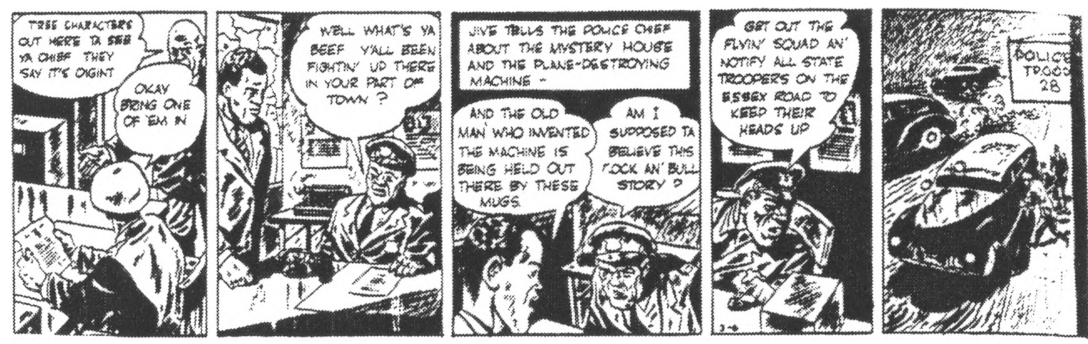

Figure 6 . When one is black, not only does the cavalry not arrive in time - it takes considerable pleading just to rouse it from its inertia.

ful escape. When the police arrive, the mansion is deserted. Who knows whether they might have been captured if the police chief had acted with more alacrity? (Or was it even intentional? Was the chief deliberately stalling?)

As Jive Gray continues into the late 1940s, Harrington offers weekly panels that more often seem designed to provide a distinctly political charge to their black readership than to further the particulars of a narrative line. Individual weekly strips may be memorable, then, for the opportunity they offer to allow characters to talk back to their opposition, or for ironic observations to be aired that might otherwise go unsaid. Whole episodes, then, turn entirely upon remarks made in passing; the larger narrative of the plot, for that particular week, remains untouched. Admiring the flying skills of Gray and his friend Waterloo, two observers from a Latin American country are made to remark. "Ah, Senor Garcia, these two, they fly like the angels. Eh, eef they join us we weel be very fortunate, I theenk. Dios, such a magnificent buzz on the airport!" "Si, si, amigo. Like the great eagles they fly. So strange een their own country they are not more admired" (3 April 1948). In another episode, someone asks Gray why he is not employed as an airline pilot, so he has the chance to explain: "back in the good old USA we'd never get a chance to fly for the airlines unless we bleached out some" (7 August 1948).

African American newspaper comic strips in the postwar years, as historian Bruce Lenthall has argued, generally became "combative, aggressive, demanding" (55). At times the weekly episode of Jive Gray indeed offered a dose of politics that was startlingly savage and partial, an aggressive countering of racism with a counterimagery that risks seeming blunt and reductive. In an episode from July 17, 1947, underlings inform their white supremacist leader that the scientist they are seeking has been traced to a location in the black ghetto of a nearby city. Harrington thus advances his large-scale narrative, building suspense by revealing the enemy has targeted its quarry. But at the same time, and perhaps more importantly, we glimpse the style of thinking that marks these evil men who would rule the country, and that seems not at all fantastic but all too recognizably real. Complaining in one panel that his men have been "outsmarted" by a "doddering old black teacher," the leader remarks: "The police wouldn't be disturbed if we killed two negroes...." And in the last panel, the leader preens over his visage in a hand mirror and says to no one in particular: "Hmmm, my eyes are beautiful when I make decisions!" (17 July 1947). White supremacy and its exclusionary policies are here associated with narcissism and thus with an elite class (the leader is discovered amid sumptuous surround- 
ings, playing a grand piano); moreover, there is a degree of fastidiousness that associates him with decadence and, in the popular visual codes of the later 1940s, with effeminacy (he is wearing a gown with shiny lapels and an ascot and smokes a cigarette with a holder). In a highly compressed form, in a set of offhand comments, Harrington quickly lays bare secrets of cultural dominance, exposing racism as a form of narcissism, a secret desire that is, like the upper classes and their fetishization of high culture, ultimately decadent. But in this case, handicapped in part by another set of social conventions, he can only do so by simultaneously advancing a homophobic iconography.

When Jive Gray came to an abrupt end in 1951, Harrington had developed a strip that still appeared to have all the trappings of a rousing tale of adventure. Its distinctive black hero memorialized a historic moment in African American history - a fact that Harrington emphasized over the years with numerous allusions to Gray's past as a Tuskegee Airmen, as in Lila Diller's inventive comparison of Gray with a P-51 (29 December 1945). Gray's friend Waterloo, on being shown an actual P-51, immediately recalls the distinctive red markings on the tails of the fighter planes assigned to the 332d Fighter Group: "Oh man we ain't breezed one of those sapsuckers since the old red tails burned up the breeze in Italy" (27 December 1948). At the same time, Gray's adventures found him in areas outside America where issues of racism were foregrounded - the Caribbean, Latin America, and in his final episode, South Africa. Not surprisingly, in these "outposts" far from the U.S.A., Harrington revealed what most mainstream newspapers had been quick to forget - the triumphs and achievements of the Tuskegee Airmen were well known. In comments addressed to Gray by the African guerrilla known as "Kumbala," we learn that to some groups, the tales that were generated around the Tuskegee Airmen are more than just historical - they are in fact sharply relevant to some contemporary situations:

Oh yes we admire our dark brothers in America. Their fight is our fight. We would welcome their fine training. However, those who learned to fire a fifty-caliber in a diving Mustang would also be most welcome here! (21 January 1950)

The firepower used in one of Jive Gray's earliest episodes, where a southern mob was eliminated by a Tuskegee Airman defending his brothers, thus returns in one of the last episodes. Now, however, that early incident appears much expanded exported to an African country, generalized into the possibility of a training situation in which others will now learn how to fight back against racism, and apotheosized as a moment of bonding between Africans and Americans. "Their fight is our fight."

Here as elsewhere Harrington's achievement in Jive Gray was to unite historical awareness with revolutionary politics in a manner that made neither one particularly visible. He mixed anew the components of the adventure strip, seeking a blend that could at once entertain and educate, as well as provide examples of communal solidarity, useful role models and positive self-images. Few other examples so effectively demonstrate the strengths (and at times the weaknesses) of the adventure strip to address serious social causes. While celebrating the resourcefulness and wit of the black community, Harrington also sharply commented on the misun- 
derstandings that arose unnecessarily between its men and women. He recorded episodes in the postwar struggle by blacks to shape a life of dignity. And he did so in a popular form whose defining features he honored even as he superseded them in numerous subtle ways.

\section{Notes}

My thanks to Corey Creekmur, Kevin Dettmar, Nancy Goldstein, Cary Nelson and Katie Salzmann for their commentary and discussion that clarified earlier versions of this essay.

The newspaper comic strips entitled Jive Gray and Dark Laughter are reprinted by permission of GRM Associates, Inc., Agents for the Estate of Ida M. Cullen, from the Pittsburgh Courier, issues of 7-14-45, 5-8-43, 9-15-45, 4-20-46, 3-6-48 and 6-1050. Copyright (C) 1943, 1945, 1946, 1948, 1950, The Pittsburgh Courier.

\section{Works Cited}

Allen, Irving Lewis. The City in Slang: New York Life and Popular Speech. New York: Oxford UP, 1993.

Buhle, Paul and Dave Wagner. Radical Hollywood: The Untold Story behind America's Favorite Movies. New York: New Press, 2002.

Milton Caniff. Terry and the Pirates 13: "Out of the Frying Pan." 1941. New York: Nantier, Beall, Minoustchine, 1989.

---. Terry and the Pirates 23: The Unsurrendered. 1945-1946. New York: Nantier, Beall, Minoustchine, 1992.

Caswell, Lucy Shelton. “Oliver Harrington: A Biographical Sketch.” In Cartoons and Ethnicity. Columbus, OH.: Ohio State U Libraries, 1992. 67-70.

Daniels, Roger. "Bad News from the Good War: Democracy at Home during World War II." In The Home-Front War: World War II and American Society. Ed. Kenneth Paul O'Brien and Lynn Hudson Parsons. Westport, CT.: Greenwood, 1995. 158-172.

Goulart, Ron. The Funnies: One Hundred Years of American Comic Strips. Holbrook, MA.: Adams, 1995.

Gordon, Ian. Comic Strips and Consumer Culture, 1890-1945. Washington: Smithsonian U P, 1998.

Gould, Chester. Dick Tracy. 6 May 1936, 8 May 1936. Dick Tracy Magazine 14 (1994). 476, 477.

Harrington, Oliver. Jive Gray. Pittsburgh Courier (Pittsburgh, PA.). 8 May 1943

to 1 Jan. 1944 and 24 Feb 1945 to 16 June 1951. Continental Features Syndicate.

Hayward, Jennifer. Consuming Pleasures: Active Audiences and Serial Fictions from Dickens to Soap Opera. Lexington, KY.: U P of Kentucky, 1997.

Homan, Lynn M. and Thomas Reilly. The Tuskegee Airmen. Charleston, S.C.:

Arcadia, 1998.

Inge, Thomas M. "Introduction." In Dark Laughter: Satiric Art of Oliver W. 
Harrington. Ed. Thomas M. Inge. Jackson, MS.: U P of Mississipi, 1993. vii-xl. "Jive." Dictionary of American Regional English. Chief ed. Fredric J. Cassidy,

Assoc. Ed., Joan Houston Hall. Cambridge: Harvard U P, 1996.

"Jive." From Juba to Jive: A Dictionary of African-American Slang. Ed.,

Clarence Major. New York: Viking, 1994.

Johnson, Charles. "Foreword." Black Images in the Comics: A Visual History. By

Fredrik Strömberg. Seattle, WA.: Fantagraphics, 2003. 6-18.

Lenthall, Bruce. "Outside the Panel - Race in America's Popular Imagination:

Comic Strips Before and After World War II.” Journal of American Studies 32 (1998): 39-61.

Lott, Eric. “Double V, Double Time: Bebop's Politics of Style." 1988. In The Jazz

Cadence of American Culture. Ed. Robert G. O’Meally. New York: Columbia U P, 1998.457-468.

Mauldin, Bill. Up Front. 1944. In Reporting World War II: Part Two, American Journalism 1944-1946. Ed. Samuel Hynes, Anne Matthews, Nancy Caldwell

Sorel, and Roger J. Spiller. New York: Library of America, 1995. 276-469.

Mazyck, Robin. "Time for Action: World War II through the Eyes of an African-

American Cartoonist."MA Thesis. Michigan State U, 1998.

Meyerowitz, Joanne. "Beyond the Feminine Mystique: A Reassessment of

Postwar Mass Culture, 1946-1958.” In Not June Cleaver: Women and Gender in Postwar America, 1945-1960., Ed. Joanne Meyerowitz. Philadelphia:

Temple UP, 1994. 229-262.

Mitchell, W. J. T. Picture Theory. Chicago: U Chicago P, 1994.

Robbins, Frank. Johnny Hazard, First Series: 1. 1944-1945. Genova (Italy):

Silvano Scotto, 1993.

Scott, Lawrence P. and William H. Womack, Sr. Double V: The Civil Rights

Struggle of the Tuskegee Airmen. East Lansing, MI.: Michigan State U P, 1994. Shaw, Patricia Ann Friday. "Negro Digest," "Pulse" and "Headlines and

Pictures": African American Periodicals as Informants, Morale Builders and Articulators of Protest During World War II. Diss: U Maryland, College Park, 1994. Ann Arbor: UMI, 1995.

Sklaroff, Lauren Rebecca. "Variety for the Servicemen: The Jubilee Show and the Paradox of Racializing Radio during World War II." American Quarterly 56 (2004), 945-973.

Stormy Weather. Screenplay by Hy Kraft. Perf. Lena Horne, Bill Robinson, and Cab Calloway. Twentieth-Century Fox, 1943.

Washburn, Patrick S. A Question of Sedition: The Federal Government's Investigation of the Black Press During World War II. New York: Oxford U P, 1986. 